\title{
ANALISIS DRUG RELATED PROBLEMS (DRPS) PADA PASIEN ACUTE CORONARY SYNDROME DI RSUD ABDUL WAHAB SJAHRANIE SAMARINDA
}

\author{
Desi A. Aditamasari*, Hanggara Arifian, Adam M. Ramadhan \\ Laboratorium Penelitian dan Pengembangan Kefarmasian "Farmaka Tropis", \\ Fakultas Farmasi, Universitas Mulawarman, Samarinda, Indonesia \\ *Email: desi.aditamasari@gmail.com
}

\begin{abstract}
The use of many drugs or called polypharmacy in acute coronary syndrome patients can cause Drug Related Problems (DRPs). DRPs analysis are needed to optimize the therapy provided. The research has been done to know characteristics and find number of cases DRPs acute coronary syndrome patients. This study used a observational design. Capture patient data prospectively and descriptively analyzed from medical records. The inclusion criteria were patients with acute coronary syndrome, adult, and hospitalization at Abdul Wahab Sjahranie Hospital in Samarinda from August to October 2018. The results of the study showed that DRP's analysis was found, indications without drugs (13.33\%), overdose (3.33\%), adverse drug reaction (20\%) and drug interactions (80\%).
\end{abstract}

Keywords: Acute coronary syndrome, drug related problems, prospectively

\begin{abstract}
ABSTRAK
Pemakaian obat yang cukup banyak atau disebut polifarmasi pada pasien acute coronary syndrome dapat menyebabkan terjadinya Drug Related Problems (DRPs). Analisis DRPs perlu dilakukan untuk mengoptimalkan terapi yang diberikan. Tujuan penelitian yaitu untuk mengetahui karakteristik dan jumlah kejadian DRPs pada pasien acute coronary syndrome. Penelitian ini menggunakan rancangan penelitian observasional. Data diambil secara prospektif dengan mencatat rekam medik pasien dan dianalisis secara deskriptif. Kriteria inklusi adalah pasien acute coronary syndrome, dewasa, dan rawat inap di RSUD Abdul Wahab Sjahranie Samarinda dalam rentang periode Agustus-Oktober 2018. Hasil penelitian menunjukkan analisis DRP's yang ditemukan yaitu indikasi tanpa obat $(13,33 \%)$, overdose (3,33\%), adverse drug reaction (20\%) dan drug interactions (80\%).
\end{abstract}

Kata kunci: Acute coronary syndrome, drug related problems, prospektif

DOI: https://doi.org/10.25026/mpc.v8i1.322

PENDAHULUAN

Acute coronary syndrome

merupakan istilah yang mencakup spektrum kondisi klinis yang ditandai dengan iskemia miokard secara akut. Acute coronary syndrome diakibatkan 
karena adanya ketidakseimbangan antara ketersediaan oksigen dengan kebutuhannya [1]. Berdasarkan luasnya presentasi klinis acute coronary syndrome mengacu adanya segmen $S T$ elevation myocardial infarction, Non ST elevation infarction dan unstable angina pectoris [2].

Acute coronary syndrome membutuhkan obat yang kompleks terkait pengobatan yang menyebabkan ketidakefisiensi terapi obat, sehingga dapat memicu drug related problems (DRPs). DRPs dapat dicegah dengan intervensi farmasis atau apoteker. Sehingga, analisis DRPs perlu dilakukan dalam upaya mengoptimalkan terapi yang diberikan. DRPs merupakan kejadian atau pengalaman yang dialami pasien tidak diharapkan berkaitan dengan terapi obat dan secara aktual maupun potensial mempengaruhi outcome terapi pasien [3].

Menurut penelitian yang dilakukan oleh Abraham 2013 ditemukan kejadian DRPs yang tinggi pada penggunaan obat kardiovaskular yaitu kategori obat hipertensi, antiplatelet, antikoagulan, dislipidemia, dan antirefluks atau antiulserasi [4]. DRPs yang sering terjadi pada penyakit kardiovaskular antara lain; interaksi obat, dosis obat terlalu tinggi, dosis obat terlalu rendah, pemilihan obat yang tidak tepat, adverse drug reaction, indikasi tanpa obat dan gagal menerima obat.

Berdasarkan hal tersebut untuk memaksimalkan terapi pasien salah satu upaya yang dapat dilakukan yakni menganalisis karakteristik dan kejadian DRPs pada pasien acute coronary syndrome rawat inap di RSUD Abdul Wahab Sjahranie Samarinda. Informasi mengenai jumlah kejadian DRPs ini sangat dibutuhkan agar manajemen terapi pengobatan dapat tercapai.

\section{METODE}

Penelitian ini menggunakan rancangan penelitian observasional. Pengambilan data penelitian dilakukan secara prospektif dengan mencatat rekam medik pasien. Teknik pengambilan sampel yaitu purposive sampling pada pasien acute coronary syndrome rawat inap di RSUD Abdul Wahab Sjahranie Samarinda selama periode AgustusOktober 2018.

Populasi penelitian adalah seluruh pasien acute coronary syndrome rawat inap di RSUD Abdul Wahab Sjahranie Samarinda. Sampel penelitian adalah pasien acute coronay syndrome yang termasuk dalam kriteria inklusi. Kriteria inklusi dalam penelitian ini yaitu pasien dewasa, laki-laki dan perempuan antara usia 18-85 tahun, didiagnosa acute coronary syndrome dengan atau tanpa komplikasi dan menerima obat.

Pengumpulan data dilakukan dengan lembar pengumpul data yang memuat nomor rekam medik pasien, usia, jenis kelamin, lama dirawat, obat yang digunakan, dosis obat dan data laboratorium. Data yang diperoleh selanjutnya dianalisa secara deskriptif meliputi karakteristik pasien dan kejadian DRPs.

\section{HASIL DAN PEMBAHASAN}

\section{Gambaran Karakteristik Pasien Acute Coronary Syndrome}

Responden yang dikumpulkan pada penelitian ini sebanyak 30 pasien. Selanjutnya dianalisis karakteristik berdasarkan usia, jenis kelamin dan jangka waktu perawatan. Gambaran demografi pasien acute coronary syndrome rawat inap di RSUD Abdul Wahab Sjahranie disajikan pada tabel 1.

Berdasarkan hasil penelitian dapat diketahui jumlah pasien laki-laki sebanyak 15 pasien (50\%) dan perempuan sebanyak 15 pasien $(50 \%)$. Kejadian penyakit jantung koroner pada perempuan premenopouse sangat rendah setelah menopause karena terjadi peningkatan faktor risiko aterogenik. Hal ini, berkaitan dengan menurunnya kadar estrogen diikuti dengan disfungsi endotel 
arteri koroner yang ditandai dengan berkurangnya vasodilatasi normal sebagai respon terhadap faktor stress, sehingga kejadiannya cenderung meningkat [5]. Perbedaan jenis kelamin mempengaruhi struktur pembuluh darah. Perempuan memilki tipe pembuluh darah yang lebih kecil dan perbedaan diameter saluran pembuluh darah dengan laki-laki. Hal ini juga dipengaruhi pada tinggi tekanan darah. Akan tetapi, bila dikaitkan dengan nyeri dada antara laki-laki dan perempuan tidak mempunyai perbedaan yang signifikan, karena toleransi terhadap nyeri dipengaruhi oleh faktor-faktor biokimia dan merupakan hal unik bagi setiap individu, tanpa memperhatikan jenis kelamin [6].

Tabel 1. Data Demografi pasien

\begin{tabular}{|c|c|c|}
\hline Karakteristik & Jumlah Pasien $(n=30)$ & $\%$ \\
\hline \multicolumn{3}{|l|}{ Jenis Kelamin } \\
\hline Laki-laki & 15 & 50 \\
\hline Perempuan & 15 & 50 \\
\hline \multicolumn{3}{|l|}{ Usia (tahun) } \\
\hline $26-45$ & 5 & 16,67 \\
\hline $46-65$ & 19 & 63,33 \\
\hline$>65$ & 6 & 20 \\
\hline \multicolumn{3}{|c|}{ Lama dirawat (hari) } \\
\hline $2-4$ & 5 & 16,67 \\
\hline $5-7$ & 14 & 46,67 \\
\hline$>7$ & 11 & 36,67 \\
\hline
\end{tabular}

Selain itu, adanya kerusakan pembuluh arteri juga dapat dikaitkan dengan riwayat status merokok pada pasien. Teori menunjukan bahwa dua efek utama dari merokok yang berperan penting dalam perkembangan penyakit jantung koroner adalah efek nikotin dan denaturasi hemoglobin oleh carbon monoksida (CO). Nikotin berperan penting untuk terjadinya aterosklerosis koroner dan thrombosis dengan mekanisme menaikkan asam lemak bebas serta meningkatkan kelekatan dan agregasi trombosit melalui stimulasi katekolamin. Kebiasaan merokok juga dapat meningkatkan kejadian koroner akut dimana karbon monoksida menyebabkan hipoksia jaringan arteri, nikotin menyebakan mobilisasi katekolamin yang dapat menambah reaksi trombosit dan menyebabkan kerusakan dinding arteri [7].
Usia sangat rentan terhadap peningkatan ateroskeloris koroner pada penyakit jantung. Berdasarkan tabel 1 rentang usia 46-65 tahun memiliki angka kejadian acute coronary syndrome yaitu dengan presentase sebesar $63,33 \%$. Hal ini diperkirakan seiring bertambahnya usia terjadi penurunan fungsi organ dalam tubuh salah satunya terjadi penurunan elastisitas arteri sehingga pembuluh darah akan berangsur-ansur menyempit dan menjadi kaku. Peningkatan usia menyebabkan perubahan anatomik dan fisiologik pada jantung dan pembuluh darah bahkan di seluruh organ tubuh manusia, keadaan ini dihubungkan dengan adanya peningkatan kadar kolesterol total.

Durasi pasien lama dirawat menunjukkan bahwa sebagian besar pasien acute coronary syndrome menjalani rawat inap di RSUD Abdul Wahab Sjahranie selama 5-7 hari 
sebanyak 14 pasien (46,67\%), dapat dilihat bahwa lama dirawat pasien acute coronary syndrome cenderung membutuhkan waktu yang lama dalam proses penyembuhannya selama berada di rumah sakit. Selain dari usia pasien, hal yang perlu diperhatikan adalah kondisi pasien dan tingkat keparahan penyakit penyerta [8].

\section{Analisis Drug Related Problems (DRPs)} Drug Related Problems (DRPs) adalah kejadian yang tidak diharapkan terkait terapi obat sehingga mengganggu keberhasilan terapi yang diinginkan. Kejadian DRPs yang diteliti pada penelitian ini antara lain, indikasi tanpa obat, underdose dan overdose, adverse drug reaction, dan drug interactions.

Tabel 2. Kategori DRPs Indikasi tanpa Obat

\begin{tabular}{lcc}
\hline Kriteria indikasi & $\begin{array}{c}\text { Jumlah } \\
\text { Pasien }\end{array}$ & $\%$ \\
\hline $\begin{array}{l}\text { Indikasi tepat } \\
\text { Indikasi tanpa } \\
\text { obat }\end{array}$ & 26 & 86,67 \\
\hline
\end{tabular}

\footnotetext{
Penggunaan obat kategori tepat indikasi dilakukan dengan cara membandingkan diagnosa yang tertulis direkam medik dan pemeriksaan laboratorium juga berpengaruh terhadap terapi obat yang diberikan terkait kondisi pasien. Berdasarkan hasil penelitian ditemukan adanya indikasi tanpa obat, terdapat 4 pasien $(13,33 \%)$ yang memiliki indikasi hiperurisemia baik yang tertulis dalam rekam medik maupun hasil laboratorium namun tidak diberikan terapi. Seharusnya pasien diberikan obatobatan gout, misalnya allopurinol untuk mengontrol kadar asam uratnya. Selain itu, diimbangi dengan diet rendah purin karena kadar asam urat yang tinggi dalam tubuh dapat menyebabkan penurunan
}

fungsi ginjal, meningkatkan risiko penyakit kardiovaskular.

Tabel 3. Kategori DRPs Underdose dan Overdose

\begin{tabular}{lcc}
\hline \multicolumn{1}{c}{ Kriteria } & Jumlah & $\%$ \\
ketepatan dosis & Pasien & $\%$ \\
\hline Dosis tepat & 29 & 96,67 \\
Dosis berlebih & 1 & 3,33 \\
Dosis kurang & 0 & 0 \\
\hline
\end{tabular}

DRPs ketepatan dosis dilakukan dengan cara membandingkan dosis obat yang diberikan kepada pasien dengan beberapa literatur yang digunakan sebagai acuan atau standar terapi dalam perhitungan dosis. Pemberian obat dengan dosis sub terapi mengakibatkan ketidakefektifan terapi obat dan outcome terapi yang diharapkan tidak tercapai [9]. Dikatakan tepat dosis apabila dosis yang diberikan berada dalam dosis lazim untuk pasien acute coronary syndrome. Hasil penelitian menunjukkan bahwa ketepatan dosis dalam penelitian ini adalah sebesar 96,67\% dan tidak tepat dosis dosis sebesar 3,33\%. Berdasarkan literatur yang digunakan ditemukan dosis berlebih pada pemberian nitroglyserine menurut literatur dosis lazim penggunaan nitroglyserine yaitu $2-3 \times 2,5-5 \mathrm{mg} / \mathrm{hari}$, tetapi terdapat 1 pasien yang diberikan $3 \times 10 \mathrm{mg} /$ hari [10][11]. Ketepatan dosis sangat diperlukan dalam keberhasilan terapi, jika dosis obat kurang dapat menyebabkan terapi yang tidak optimal. Sedangkan pada dosis lebih dapat menyebabkan toksik [12].

Tabel 4. Kategori DRPs Adverse Drug Reaction

\begin{tabular}{lcc}
\hline \multicolumn{1}{c}{ Jenis Obat } & $\begin{array}{c}\text { Adverve Drug } \\
\text { Reaction }\end{array}$ & $\begin{array}{c}\text { Jumlah } \\
\text { Kasus }\end{array}$ \\
\hline Furosemide & Hiperurisemia & 5 \\
Spironolactone & Hyponatremia & 2 \\
\hline
\end{tabular}


Adverse drug reaction (ADR) merupakan kejadian respon tubuh terhadap obat yang bersifat merugikan atau berbahaya dan tidak diinginkan yang terjadi pada dosis normal yang digunakan pada pasien acute coronary syndrome rawat inap di RSUD Abdul Wahab Sjahranie Samarinda terdapat 6 pasien (20\%) dari jumlah total 30 pasien, sehingga perlu dilakukan monitoring terhadap efek obat yang digunakan untuk mengurangi kejadian efek obat tersebut. Efek obat ini dapat disebabkan oleh penggunaan obat tersebut dalam jangka waktu panjang, atau dapat pula disebabkan oleh dosis penggunaan obat yang berlebih.

Beberapa obat juga berkontribusi dalam meningkatkan kadar asam urat serum melalui penurunan ekskresi akibat adanya kompetisi antara asam urat dengan obat-obat tersebut di dalam tubulus ginjal. Agen diuretik memiliki mekanisme yang berbeda dalam menghambat ekskresi asam urat. Agen diuretik loop seperti furosemide akan meningkatkan reabsorpsi asam urat di dalam tubulus ginjal sehingga dapat menyebabkan hiperurisemia sebesar $40 \%$. Diuretik loop memiliki kemampuan yang lebih besar dibanding agen thiazid lain seperti hidroklorotiazid dalam mengekskresi asam urat sedangkan spironolakton memiliki kemampuan lebih kecil dalam mengeksresi asam urat dibandingkan hidroklorotiazi [13].

Peningkatan asam urat ini dapat terjadi pada pasien yang telah menderita asam urat sebelumnya ataupun pasien yang tidak menderita asam urat sebelumnya. Peningkatan asam urat ini hanya bersifat sementara saja dan nilai asam urat akan kembali normal jika penggunaan furosemide ini dihentikan atau dapat juga digunakan allopurinol untuk mengatasi peningkatan asam urat yang signifikan [14]. Pada penelitian ini, didapatkan hasil kadar asam urat yang melebihi rentang normal pada pasien yang menggunakan obat-obatan diuretik yaitu furosemide.

Penggunaan spironolactone dapat menyebabkan meningkatnya jumlah natrium dan air yang akan diekskresikan sehingga terjadinya hyponatremia. Hal ini dikarenakan spironolactone merupakan antagonis aldosteron yamg spesifik, terutamanya bertindak dengan cara pengikatan kompetitif reseptornya dikanal pertukaran natrium-kalium yang sifatnya aldosterone dependent didalam tubulus distal [15].

Tabel 5. Kategori DRPs Drug Interactions

\begin{tabular}{llc}
\hline & \multicolumn{1}{c}{ Obat B } & $\begin{array}{c}\text { Jumlah } \\
\text { Kasus }\end{array}$ \\
\hline Aspirin & Fondaparinux & 13 \\
Clopidogrel & Fondaparinux & 11 \\
Simvastatin & Amlodipine & 8 \\
\hline
\end{tabular}

Interaksi obat adalah suatu interaksi yang terjadi ketika efek suatu obat diubah oleh kehadiran obat lain [16]. Interaksi obat pada data rekam medis yang diambil di RSUD Abdul Wahad Sjahranie Samarinda diidentifikasi dengan drug interaction checker (drug.com) dari 30 pasien acute coronary syndrome terdapat 24 pasien $(80 \%)$ yang mengalami interaksi obat dan 6 pasien (20\%) yang tidak mengalami interaksi obat.

Interaksi antara clopidogrel dan fondaparinux dapat menyebabkan komplikasi perdarahan (bleeding/ haemorrhage) yang terkait dengan penggunaan low molecular weight heparin (LMWH). Clopidogrel adalah prodrug yang dimetabolisme di hati oleh CYP2C19 menjadi metabolit aktif dan menghasilkan efek antiagregasi trombositnya. Metabolit clopidogrel dapat menghambat enzimatik aktivitas sitokrom P4502C9 dan meningkatkan kadar plasma NSAID sehingga dapat 
terjadi peningkatan perdarahan gastrointestinal. Interaksi antara aspirin dan fondaparinux dengan mekanisme farmakodinamik, NSAID diketahui dapat menyebabkan perdarahan gastrointestinal terkait dosis, jika diberikan secara kronis atau dalam dosis tinggi. NSAID dapat menyebabkan perdarahan pada saluran cerna dikarenakan penghambatan enzim COX-1 yang berperan dalam proteksi saluran cerna $[17,18]$.

Interaksi antara amlodipine dan simvastatin merupakan interaksi farmakokinetik dengan kategori interaksi mayor karena terjadi pada fase metabolisme, amlodipin secara signifikan meningkatkan AUC HMG-CoA reductase inhibitors setelah pemberian simvastatin. Karena amlodipine mengganggu proses eliminasi statin dengan menghambat CYP450 3A4, dimana simvastatin merupakan substratnya sehingga kadar simvastatin meningkat. Obat ini sering digunakan bersamaan untuk pasien dengan hipertensi dan hiperkolesterolemia [19]. Penggunaan kombinasi simvastatin dan amlodipin tidak perlu dihindari, namun disarankan agar pengobatan dengan statin pada pasien hipertensi dimulai dengan dosis statin serendah mungkin untuk membatasi dosis sampai $20 \mathrm{mg}$ setiap hari [20].

Menurut mallet 2007, beberapa hal berikut dapat dipertimbangkan dalam manajemen interaksi, yaitu mendokumentasikan secara lengkap riwayat pengobatan, meninjau kembali pengobatan untuk memperbaharui kemungkinan terjadi interaksi obat, ketahui dan dokumentasikan interaksi terbaru pada catatan kesehatan dengan cara penanganan, pantau efek tidak diinginkan dari potensi interaksi obat. Hasil sebuah penelitian yang dilakukan Kaffel 2014 menyatakan bahwa mayoritas interaksi dapat dengan mudah dihindari dengan memodifikasi dosis, pengecekan kembali resep. Dalam system pelayanan kesehatan, upaya dari penulisan resep dan peracikan sangat penting agar terapi bagi pasien bermanfaat [21][22].

\section{KESIMPULAN}

Berdasarkan hasil penelitian yang telah dilakukan di RSUD Abdul Wahab Sjahranie Samarinda dapat disimpulkan bahwa rentang usia penderita acute coronary syndrome 46-65 tahun $(63,33 \%)$, dengan jenis kelamin laki-laki $(50 \%)$ dan perempuan $(50 \%)$ serta lama dirawat pada rentang 5-7 hari $(46,67 \%)$. Analisis DRPs yang ditemukan yaitu indikasi tanpa obat $(13,33 \%)$, overdose (3,33\%), adverse drug reaction (20\%) dan drug interaction (80\%).

\section{UCAPAN TERIMAKASIH}

Terimakasih kepada Pimpinan RSUD Abdul Wahab Sjahranie Samarinda atas izin dan bantuan yang diberikan selama penelitian.

\section{DAFTAR PUSTAKA}

[1] Dipiro. 2009. Pharmacotherapy: A Pathophysiologic Approach $7^{\text {th }}$ Edition. USA: The McGraw-Hill Companies, Inc.

[2] Departemen Kesehatan RI. 2007. Pharmaceutical care untuk pasien penyakit jantung koroner: focus sindrom koroner akut. Jakarta: Direktorat Bina Farmasi Komunitas dan Klinik,Ditjen Bina Kefarmasian dan Alat kesehatan Dep.Kes RI.

[3] Cipolle, R.J. 2004. Drug Therapy Problem: In Pharmaceutical Care Practie The Clinician's Guide second edition. New York: The McGrawHill Companies.

[4] Abraham, R.R. 2013. Drug Related Problems and Reactive Pharmacist Interventions for Inpatients Receiving Cardiovascular Drug. International Journal of Basic Medical Sciences and Pharmacy (IJBMSP).

[5] Antman, E.M. 2001.Acute Myocardial Infarction. In Braunwald 
Heart Disease: A Textbook of Cardiovascular Medicine, $6^{\text {th }} e d . \mathrm{Wb}$ Saunders Co.

[6] Potter. 2005. Fundamental Keperawatan Konsep, Proses dan Praktik. Jakarta: ECG.

[7] Cipto, S. 2013. Hubungan Luas Infark Miokard (berdasarkan skor selvester) dengan respon nyeri dada pada pasien syndrome coroner akut (SKA) di RSD Dr. Soebandi Jember. Jurnal Ilmu Keperawatan. Vol 1 No 2.

[8] Astutik, Widi., Didik, H., Nailis, S. 2013. Penggunaan Obat Golongan Diuretik pada Pasien Stroke Iskemik di Instalasi Rawat Inap Rsu Dr. Saiful Anwar Malang. Media Farmasi.

[9] Susilowati. 2008. Pengukuran Status Gizi Dengan Antropometri Gizi. Jakarta: CV. Trans Info Media.

[10]Aberg, J.A. 2009. Drug Information Handbook, 17th edition. American: Lexi-Comp.

[11]Perhimpunan Dokter Spesialis Kardiovaskular Indonesia (PERKI). 2015. Pedoman Tatalaksana Gagal Jantung (edisi pertama). Jakarta: PERKI.

[12]Priyanto. 2009. Farmakoterapi dan Terminologi Medis. Depok: Leskonfi.

[13]Ema, P.Y. 2018. Hubungan antara Obesitas, Konsumsi Tinggi Purin, dan Pengobatan terhadap Kadar Asam Urat dengan Penggunaan Allopurinol pada Pasien Hiperurisemia. Jurnal Farmasi Klinik Indonesia. Vol.7 No. 1. ISSN: 2252-6218
[14]Well, dkk. 2000. Pharmacotherapy handbook $2^{\text {nd }} E d$. Appleton and lange. Connecticut.

[15]Briet, M. 2010. Aldosterone: effects on the kidnay and cardiovascular system. Nat rev nephron.

[16] Yesia,SM. 2017. Kajian Potensi Interaksi Obat Antihipertensi Pada Pasien Hipertensi Primer Di Instalasi Rawat Jalan Rsud Luwuk Periode Januari - Maret 2016. Pharmacon Jurnal Ilmiah Farmasi. UNSRAT Vol. 6 No. 3

[17]Drug Interaction Checker. 2018 In : www.drug.com/druginteraction.html

[18] Yusuf, S. 2006. Comparison of Fondaparinux and Enoxaparin in Acute Coronary Syndromes.The New England Journal of Medicine.

[19]Nishio. 2005. Interaction between Amlodipine and Simvastatin in Patients with Hypercholesterolemia and Hypertension. Japan: Department of Clinical Pharmacology and Therapeutics and Department of Internal Medicine III, Hamamatsu University School of Medicine, Hamamatsu. Pharmacists Association

[20] Stockley, I.H. 2008. Stockley's Drug Interaction. Eighth Edition. London: Pharmaceutical Press.

[21] Mallet, L, dkk. 2007. The Challenge of Managing Drug Interactions in Elderly People. Lancet.

[22] Kafeel, H. 2014, Possibility of DrugDrug Interaction in Prescription Dispensed by Community and Hospital Pharmacy. Pharmacology and Pharmacy. 